\title{
The Earliest Jewish Embassy to the Romans: 2 Macc. 4:11?
}

\author{
L. T. ZOLLSCHAN \\ Department of History, \\ Ben-Gurion University of the Negev, Beersheva
}

T $\mathrm{n}$ a well-known passage in 2 Maccabees one finds a report of an embassy 1 to the Romans placed in the middle of a short account of the reforms of the High Priest Jason (2 Macc. 4:11). For the reader's convenience I reproduce the Greek text as edited by Kappler and Hanhart: ${ }^{1}$

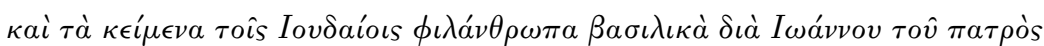

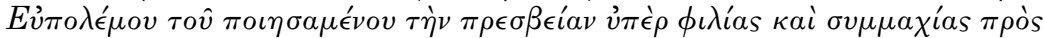

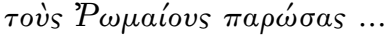

Virtually all commentators identify the ambassador as Eupolemus and assume the embassy must be that of Jason and Eupolemus sent by Judas Maccabaeus to Rome in $161 \mathrm{BCE}^{2}$ The near unanimous consensus is that 2 Macc. 4:11 constitutes a valuable corroborating piece of evidence for the embassy of 161 BCE. A few dissenting voices have expressed some disquiet about the unusual manner in which John is identified through his son; but, for the most part, no challenge has been issued to the identification of Eupolemus as the

1 W. Kappler and R. Hanhart, Maccabaeorum liber II (Vandenhoeck \& Ruprecht, Göttingen, 1976), p. 61. A translation according to Zeitlin reads: 'He [Jason] set aside the established royal laws favourable to the Jews, which had been obtained by John, father of Eupolemus, when he went as ambassador to the Romans to establish a friendly alliance.' S. Zeitlin (ed.), The Second Book of Maccabees, trans. S. Tedesche (Harper, New York, 1954), p. 133.

2 The first to do so was Hugo Grotius: 'Patrem denotat ex filio, qui ob gestam postea legationem notissimus erat omnibus' as quoted by C. L. W. Grimm, Das zweite, dritte und vierte Buch der Maccabäer (S. Hirzel, Leipzig, 1857), p. 81, and endorsed by him, pp. 81-82. Grimm's interpretation was been widely followed: B. Niese, 'Kritik der beiden Makkabäerbücher', Hermes 35 (1900), p. 501; J. Knabenbauer, Commentarius in duos libros Machabaeorum (P. Lethielleux, Paris, 1907), p. 319; F.-M. Abel, Les Livres des Maccabées (Libraire Lecoffre, Paris, 1949), p. 333, n. 11; H. Bévenot, Die beiden Makkabäerbücher (Die Heilige Schrift des Alten Testaments, IV/4, Bonn, 1931), p. 187, n. 11; S. Zeitlin, The Second Book of Maccabees (as in n. 1), p. 133; A. Penna, ' $\Delta \iota a \theta \eta^{\prime} \kappa \eta$ e $\sigma v \nu \theta \eta \dot{\kappa} \eta$ nei libri dei Maccabei', Biblica 46 (1965), p. 153 ; M. Sordi, 'L'elogio dei Romani nel I libro dei Maccabei' in Storiografia e propaganda, vol. 3 (Università Cattolica del Sacro Cuore, Milan, 1975), p. 103; C. Habicht, 2. Makkabäerbuch (Jüdische Schriften aus hellenistischrömischer Zeit, Band 1) (Gerd Mohn, Gütersloh, 1976), p. 217; J.-D. Gauger, Beiträge zur jüdischen Apologetik (Bonner biblische Beiträge, 49, Cologne/Bonn, 1977), p. 167; J. A. Goldstein, II Maccabees, The Anchor Bible, 41A (Garden City, N. Y., 1983), pp. 228-29; E. S. Gruen, The Hellenistic World and the Coming of Rome (University of California Press, Berkeley/Los Angeles/London, 1984), p. 43, n. 161; M. Stern, 'The Treaty between Judaea and Rome in 161 BCE', Zion 51 (1986), p. 22 (in Hebrew); B. Bar-Kochva (1989) Judas Maccabaeus: The Jewish Struggle against the Seleucids (Cambridge University Press, Cambridge, 1989), p. 181; D. Gera, Judaea and Mediterranean Politics 219 to 161 BCE (Brill, Leiden, 1998), p. 304; J. J. Collins, The Hellenization of Jerusalem in the Pre-Maccabean Era, International Rennert Guest Lecture Series, no. 6 (Jerusalem, 1999), p. 8 
ambassador to the Romans in this passage. ${ }^{3}$

There could, however, be a different interpretation altogether. A suggestion that the ambassador here referred to in our text could in fact have been not Eupolemus but his father, John, was initially made in the 1852 commentary on the passage by Keerl. He interpreted 2 Macc. 4:11 as a reference to a separate embassy with John, the father of Eupolemus as the ambassador. Thus, Keerl saw in 2 Macc. 4:11 an indication of an embassy distinct from that which went to Rome in $161 \mathrm{BCE}$ led by Eupolemus. ${ }^{4}$

The suggestion of an embassy to the Romans by John is embedded in the structure of the verse where it refers to John. A certain grammatical strangeness of the text has not aroused the kind of attention it fully deserves.

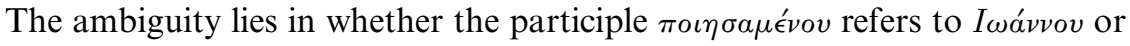
$E v \pi \pi \lambda^{\prime} \dot{\epsilon}_{\mu o v}$. Both John and Eupolemus are referred to in the genitive, John after $\delta \iota \alpha$ and Eupolemus after $\pi \alpha \tau \rho o ́ s$ so the aorist middle participle $\pi \circ \iota \eta \sigma \alpha \mu \epsilon^{\prime} v o v$ in the genitive could refer to either individual. John is introduced without a definite article before his name and this together with the repetition of $\tau o \hat{v} \ldots$ $\tau o \hat{v}$ after his name would seem to indicate that the participle refers to John. On this linguistic foundation I propose that the meaning would be that John is the father of Eupolemus and also the one who went as ambassador to the Romans.

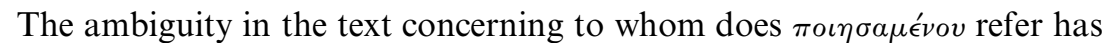
long been ignored. A severe disservice has been done by translators who have regularly obfuscated any unclarity in their work of translation. One might note, by way of example, the translation of Abel who has added the words 'this Eupolemus' to state which individual in his view was the ambassador. 'Il supprima les franchises que les rois, par humanité avaient accordées aux Juifs grâce l'entremise de Jean, père d'Eupolème (cet Eupolème qui sera envoyé en ambassade pour conclure un traité d'amitié et d'alliance avec les Romains) ....' 5

It ought to be specified what 2 Macc. 4:11 does not say. Firstly, it does not say that Jason sent John on an embassy. Neither 2 Macc. 4:10 nor verse 11 state explicitly or even infer that an embassy was sent under the instigation of Jason. Keerl asserted that the embassy was sent by Jason contrary to the actual words of the verse. Grimm took this error and used it to throw the baby out with the bath water. Grimm said that an embassy from Jason would contradict 1 Macc. 8: 'ist daher eine irrige Behauptung Keerl's'. ${ }^{6}$ Grimm was correct to the extent that Jason did not send an embassy to the Romans. Grimm's criticism of this one point, however, has caused Keerl's valid observation to

\footnotetext{
3 'It is unusual to designate a father by his son's name': V. Tcherikover, Hellenistic Civilization and the Jews, trans. S. Appelbaum (Jewish Publication Society of America, New York, 1959), p. 385 ; 'unusual use, too, of the son's name in order to identify the father' and 'the strange manner in which the latter [Eupolemus] is introduced into the verse': Bar-Kochva, Judas Maccabaeus (as in n. 2), p. 181.

4 P. F. Keerl, Die Apokryphen des Alten Testaments (Gebhardt und Reisland, Leipzig, 1852), pp. $74-76$.

5 Abel, Les Livres (as in n. 2), p. 333. See also Bévenot, Die beiden Makkabäerbücher (as in n. 2). p. 187; Zeitlin, Second Book of Maccabees (as in n. 1), p. 133.

6 Die Apokryphen (as in n. 4), p. 81.
} 
be forgotten, namely, that here was a reference to an embassy distinct from and earlier than that of 161 BCE. Grimm's own interpretation, furthermore, has shaped opinion among historians since that time.

Secondly, 2 Macc. 4:11 does not say that the embassy went to Rome. The words of the text unambiguously state that an embassy went $\pi \rho$ òs $\tau$ rov̀s P wraious and not to the city of Rome itself as in $161 \mathrm{BCE}$. When 1 Macc. 8:17 reports the embassy sent by Judas it says that Jason and Eupolemus were sent

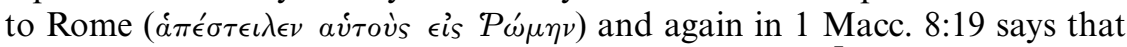

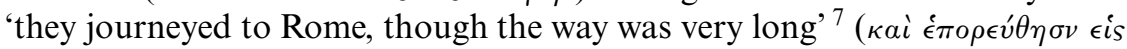

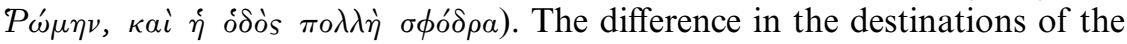
embassies referred to in 2 Macc. 4:11 and 1 Macc. 8:17, 19 indicate that we may be looking at two distinct embassies.

Only a few words remain in the verse about an embassy to the Romans; yet they may hint at the loss of a fuller account of early contacts between the Jews and the Romans. 2 Maccabees is, after all, an abridgement and considerable material may have been dropped from the original work by Jason of Cyrene. ${ }^{8}$ This was a work in five books which was said to have contained a dense mass or a large quantity of material. ${ }^{9}$ It has been estimated that between two thirds and four fifths of the original work of Jason was not included in 2 Maccabees. ${ }^{10}$ The guiding principles of abridgement are given at 2 Macc. 2:24-31; however, verse 31 shows that brevity of expression was valued by the Epitomator.

The degree to which the Epitomator compressed his material may be seen in several passages where people and events are mentioned without introduction or explanation. ${ }^{11}$ There are five passages in the book which show signs of condensation, namely, 2 Macc. 5:7; 8:1-7; 10:37; 12:36; 14:19. ${ }^{12}$ Some passages read as though they were written by the Epitomator in note form. ${ }^{13}$ One

\footnotetext{
7 Translation from S. Tedesche and S. Zeitlin, The First Book of Maccabees (Harper, New York, 1950), p. 151.

${ }^{8}$ For the suggestion that 2 Maccabees was an original work which referred to a fictional author named Jason of Cyrene: W. H. Kosters, 'De Polemiek van het tweede boek der Makkabeën', Theologisch Tÿdschrift 12 (1878), pp. 491-558; A. Kamphausen, 'Das zweite Buch der Makkabäer', Die Apokryphen und Pseudepigraphen des Alten Testaments, ed. E. Kautzsch (Mohr, Tübingen, 1900) vol. 1, pp. 81-119; W. Richnow, Untersuchungen zu Sprache und Stil den zweiten Makkabäerbuches. Ein Beitrag zur hellenistichen Historiographie (Diss. Göttingen, 1966). Contra: R. H. Pfeiffer, History of New Testament Times, with an Introduction to the Apocrypha (Harper, New York, 1949), p. 507; R. Doran, Temple Propaganda: The Purpose and Character of 2 Maccabees (CBQMS 12, Washington, 1981), pp. 81-83; J. W. van Henten, The Maccabaean martyrs as saviours of the Jewish people: a study of 2 and 4 Maccabees (Suppl. JSJ vol. 57, Brill, Leiden, 1997), p. 19.

92 Macc. 2:23 mentions five books. Dense mass of material: 2 Macc. 2:24. Large quantity: Doran, Temple Propaganda (as in n. 8) pp. 77-78.

10 Doran, Temple Propaganda (as in n. 8), pp. 81-82.

112 Macc. 4:11; 5:27; 10:37; 12:36; 14:19. See Bar-Kochva, Judas Maccabaeus (as in n. 2) p. 170 n. 53.

12 Bar-Kochva, Judas Maccabaeus (as in n. 2), idem.

132 Macc. 13:18, 19, 26. The latter verse Mugler considers unreliable. See C. Mugler, 'Remarques sur le second livre des Machabées. La statistique des mots et la question de l'auteur', Revue d'histoire et de philosophie religieuses 11 (1931), p. 420, n. 1.
} 
highly abridged passage may be found in 2 Macc. 5:27. ${ }^{14}$

Evidence of tight abridgement is indicated by the frequent use of participles to reduce a longer narrative. It has been estimated that in 2 Maccabees some passages contain 8 participles in 38 words and the entire book exhibits 90.4 participles per thousand words. ${ }^{15}$ In 2 Macc. 4:11 there are 3 participles in 24 words. ${ }^{16}$ Consequently, it appears that the Epitomator chose to delete a quantity of material from this section. Another indicator that some material has been dropped from the abridgement is the appearance of the name of John introduced without a definite article before it which indicates that the individual had been mentioned previously. As John is mentioned in this verse for the first time in the book some previous reference to him has been omitted.

Perhaps the Epitomator condensed too much, sacrificing in the process some clarity of meaning. In other places, he did not mention names and events which were obviously the subject of more detail in Jason's five-volume work. ${ }^{17}$ The Epitomator has been rightly accused of being lackadaisical in his approach to abridgement. ${ }^{18}$ The ambiguity in 2 Macc. $4: 11$ may be seen then as an unintended consequence of the Epitomator's method of working.

In addition to the ambiguity in the verse over the identity of the ambassador, there do exist other grounds to show that the Epitomator did not intend Eupolemus to be taken for the ambassador to the Romans. To suggest otherwise would be to assume that the Epitomator presented facts in his work out of strict chronological sequence. ${ }^{19}$ This goes against his practice of exercising care about chronological matters. In 2 Macc. 15:36 it states that the day set aside to celebrate the victory over Nicanor was 13 Adar to which the Epitomator has added that the festival falls on the day before Mordechai's day, that is, Purim. ${ }^{20}$ Such care about precision over dates indicates that the Epitomator would not juxtapose a reference to an embassy sent by Judas Maccabaeus among material belonging almost 13 years earlier. The Epitomator's handling of the chronology of his narrative makes it far less likely that a reference to an event in 161 BCE would be juxtaposed to events in 175-174 BCE.

As well as the Epitomator's adherence to chronological sequence, there are additional indications that he intended the Jewish embassy to the Romans to refer to John. The first is that throughout the book the Epitomator selected for inclusion material on the early diplomatic relations between Rome and

\footnotetext{
14 Bar-Kochva, Judas Maccabaeus (as in n. 2), p. 198.

15 For 8 participles: 2 Macc. 3:27-28. Compare Agoratos of Lysias: 47 participles per thousand and Polybius: 65 per thousand. Calculations by Mugler, 'Remarques' (as in n. 13), pp. 420

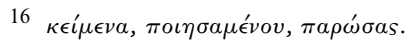

17 Cf. 2 Macc. 8:30, 32, 33; 10:19, 37; 12:36; 14:19. See Bar-Kochva, Judas Maccabaeus (as in n. 2), pp. $196-99$, n. 96.

18 E. Badian's comment cited by D. R. Schwartz, 'Apollonius, son of Menestheus: whose ambassador?', AJAH 7 (1982), p. 49, n. 4.

19 Only three places show deviation from chronological order: 2 Macc. 5:7-10; 5:27; 8:30-33. For the reasons see Bar-Kochva, Judas Maccabaeus (as in n. 2) pp. 173-78, 512, 541-42. In each case alterations were made to make a theological point. Each of these deviations from the correct order constitute passages of some length and are not a passing reference as is the mention of John in 2 Macc. 4:11.

20 Zeitlin, The Second Book of Maccabees (as in n. 1), p. 23.
} 21. 
the Jews and so revealed his interest in the contact between the Jews and the Romans. ${ }^{21} \mathrm{He}$ included a letter from two Roman legati to the Jews in 2 Macc. 11:34-38, an approach to the Jews not known from any other source. Because of this interest it is likely that he may also have included a mention of an embassy by John that is otherwise unattested in our sources. The Epitomator concluded his work with the victory over Nicanor and so did not reach the point where Jason of Cyrene dealt with the embassy of 161 BCE. Hence its omission from the work. The summary moves according to chronological sequence giving credence to the preference for reading 2 Macc. 4:11 as a reference to an embassy by John.

Another interest of the Epitomator seems to be information about Antioch that is found only in 2 Maccabees. ${ }^{22}$ The first episode involving Antioch is drawn from 2 Macc. 4:33 where it is reported that the deposed High Priest Onias III fled to Daphne near Antioch. ${ }^{23}$ This episode is one of many references to Antioch found throughout the book. ${ }^{24} \mathrm{~A}$ second example comes from chapter 7 that contains the story of the mother and her seven sons, a tale thought to be derived from Antioch. ${ }^{25}$ The third example is the letter of the Roman legati who were on their way to Antioch which the Epitomator cites in 2 Macc. 11:34-38. The Antioch connection becomes significant in the context of establishing a reason for John to have gone as ambassador but under his own auspices. The deposed High Priest Onias, according to 2 Maccabees, was spending his exile in Daphne, a suburb outside Antioch. One might speculate that John and Onias, both with their own reasons to oppose Jason, may have joined forces.

The feasibility that an embassy by John may have gone to the Romans

21 Doran, Temple Propaganda (as in n. 8), p. 111.

22 These remarks are not intended to endorse Zeitlin's view that the Epitome was written in Antioch: Zeitlin, The Second Book of Maccabees (as in n. 1), pp. 19-21. Contra: Doran, Temple Propaganda (as in n. 8), p. 113, n. 12.

23 A statement that has generated a considerable amount of scholarly discussion. See M. Stern, 'The Death of Onias III', Zion 1 (1960), pp. 1-16 (in Hebrew); M. Delcor, 'Le Temple d'Onias en Égypte', $R B 75$ (1967), pp. 188-203; R. Hayward, 'The Jewish Temple at Leontopolis: A Reconsideration', JJS 33 (1982), pp. 429-43; V. Keil, 'Onias III.-Märtyrer oder Tempelgründer?', ZAW 97 (1985), pp. 221-33; A. Wasserstein, 'Notes on the Temple of Onias at Leontopolis', Illinois Classical Studies 18 (1993), pp. 119-29; F. Parente 'Onias III's death and the founding of the temple of Leontopolis', in F. Parente and J. Sievers, eds, Josephus and the History of the GrecoRoman Period. Essays in Memory of Morton Smith (Brill, Studia Post-Biblica vol. 41, Leiden, 1994), pp. 69-98; F. Parente, 'Le témoinage de Théodore de Mopsueste sur le sort d'Onias III et la fondation du temple de Léontopolis', REJ 44 (1995), pp. 429-36; G. Vermes, 'The Leadership of the Qumran Community, the Sons of Zadok, priests, congregation', in H. Cancik, H. Lichtenberger and P. Schäfer, eds, Geschichte-Tradition-Reflexion. Festschrift für Martin Hengel, Bd I (Mohr Siebeck, Tübingen, 1996), pp. 381-84; E. S. Gruen, 'The Origins and Objectives of Onias' Temple', SCI 16 (1997), pp. 47-70; P. R. Davies, 'If the Lord's Annointed had lived', Bibl. Interp. 8 (2000), pp. 151-60.

24 References to Antioch in 2 Maccabees may be found at 4:1-7; 4:9; 4:19; 4:33; 11:34-38.

25 Considered a separate story that came from the diaspora, probably Antioch, and found already in Jason's work: U. Kellerman, Auferstanden in den Himmel: 2 Makkabäer 7 und die Auferstehung der Märtyrer (SBS 95, Stuttgart 1979), pp. 54-57. For the view that it was composed by the Epitomator who came from Antioch: Zeitlin, The Second Book of Maccabees (as in n. 1), pp. 19-20 and 24. For full references on the place of the story in 2 Maccabees: van Henten, The Maccabaean martyrs (as in n. 8), p. 18, n. 5. 
is dependent to some extent on whether an embassy by a private individual would have been accepted by the Romans. The question whether John was a legally valid representative of the Jews in Jerusalem, however, is largely irrelevant. The Romans neither knew a great deal about the Jews and their political system nor concerned themselves with the official standing of representatives when it came to receiving deputations from those with grievances against the Seleucids. One only has to note the reception given in Rome to the rebel Timarchus to see that that the senate was happy to give an audience to those whose legal standing was questionable indeed. ${ }^{26}$ For legati in the field there was much more flexibility. The behaviour of the Roman legatus, C. Sulpicius Gallus, in 164/3 BCE shows to what length Roman envoys were prepared to go in order to solicit complaints. According to Polybius (XXXI.6.1-5), Gallus posted up advertisements in all the main cities calling for those who had accusations against Eumenes, king of Pergamum, to come to Sardis and there for ten days he listened and gave credence to all accounts. It would seem unlikely in the extreme that Roman legati would have turned away complainants against a Jewish High Priest who had bribed the Syrian king to obtain the position.

The stated purpose of the embassy, according to 2 Macc. 4:11, was 'to es-

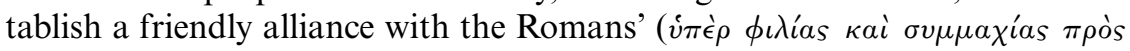
rovis P(cuaious). What can this possibly mean? The answer presented itself in the most obvious way to Grimm. ${ }^{27} \mathrm{He}$ averred that the passage provided proof positive that the embassy in $161 \mathrm{BCE}$ was meant. Surely any alliance with the Romans during the High Priesthood of Jason would contradict the clear evidence in 1 Macc. 8:21, 29, and Jos., B.J. 1:38, that only in 161 BCE was friendship and alliance established for the first time with the Romans. But do the words here signal anything as formal as the treaty (foedus) as per-

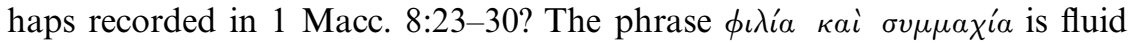
in meaning. Embassies to Rome often requested 'friendship and alliance' as a courteous first step before presenting their actual request and their reason for their embassy. ${ }^{28}$ It follows that 2 Macc. 4:11 may merely mean that John approached the Romans for a hearing as befitted a friend seeking help.

The logic of an embassy by John to the Romans at this time is certainly not inconsistent with the facts as we know them. John won royal concessions from Antiochus III which appear to be those referred to in Jos., Ant. XII:138-46. When Jason abolished these royal privileges John saw his work undone. He had the motive and the necessary experience in diplomacy to seek the reinstatement of these rights. Certainly John was not involved in assisting Jason in the abolition of these privileges as was once thought. ${ }^{29}$ For the restitution

\footnotetext{
26 Diod. 31.27a.

27 Grimm, Das zweite (as in n. 2), p. 81.

28 H. Horn, Foederati. Untersuchungen zur Geschichte ihrer Rechtsstellung im Zeitalter der römischen Republik und des frühen Principats (Diss., Bonn, 1930), p. 76; A. Heuss, Die völkerrechtlichen Grundlagen der römischen Aussenpolitik in republikanischer Zeit (Klio, Beiheft XXXI, N.F. 18, Leipzig, 1933), pp. 46, 53-59; Gruen, The Hellenistic World (as in n. 2), pp. 47, 55.

29 Luther thought John was associated with the abolition of these rights and that Jason had used John as an instrument for carrying out his Hellenising policies. Yet it is hardly to be believed
} 
of these rights an approach to Antiochus IV made no sense. However, an approach to the Romans fits the known circumstances.

But were any Romans in Syria at the time of Jason's abolition of Jewish rights? These reforms belong early in the reign of Antiochus IV who came to the throne after the death (by murder) of Seleucus IV given as Elul 10, 137 S.E. (3 September 175). ${ }^{30}$ Antiochus was proclaimed king in the 8th month of the Seleucid calendar, that is, between 23 October and 20 November 175. Therefore, the efforts of Jason to obtain the High Priesthood by petitioning Antiochus IV, as recorded in 2 Macc. 4:7-10, would have occurred after this month. ${ }^{31}$ Allowing for the sending and a return of an embassy to Antioch, the reforms mentioned in 2 Macc. 4:10-12 cannot have commenced earlier than the beginning of the year $174 \mathrm{BCE} .^{32}$ The earliest date then for any action by John would have been the beginning of the reign of Antiochus IV in October/November $175 \mathrm{BCE}$ and the latest date would have been March $174 \mathrm{BCE}$, the date for the Games of Herakles, which are reported in chapter 4:18-19.

Livy (XLII.6.12) records that a Roman embassy to Syria returned to Rome in 173 BCE: legati qui in Syria fuerant renuntiaverunt in maximo eum honore apud regem esse amicissimumque populo Romano. ${ }^{33}$ The exact nature of the embassy's mission is unknown. Livy's date for the embassy's return in 173 $\mathrm{BCE}$ is suggestive of a departure from Rome $c$. $174 \mathrm{BCE}$. This date also fits well with the timing of Antiochus IV's first embassy to Rome thought to be in early 173 BCE because the censors of $174 \mathrm{BCE}$ were still in office. ${ }^{34}$ Although this embassy finds no mention in Polybius, there are no compelling grounds to reject the Livian account. ${ }^{35}$ The chronology fits; for if the Roman legati left Rome $c .174$ BCE John would have been able to meet them either on

that the father of the Eupolemus, who was trusted by Judas Maccabaeus to be his envoy, would have had opposing views, nor that Jason as High Priest would have required a helper to abolish the Seleucid privileges. Moreover, grammatical and stylistic grounds indicate that the reading $\tau \dot{\alpha}$

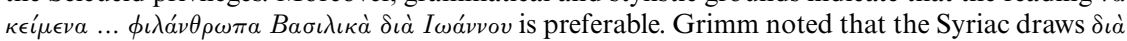

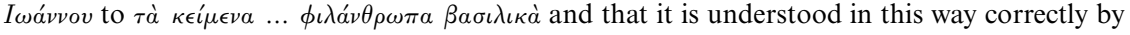
most scholars. Grimm, Das zweite (as in n. 2), pp. 81-82.

30 BM 35603 Rev. lines 8-9; Julian date from R. A. Parker and W. H. Dubberstein, Babylonian Chronology 626 BC-AD 75 (Brown University Press, Providence, 1956), p. 23; A. Jepsen and R. Hanhart, Untersuchungen zur Israelitisch-Jüdischen Chronologie, BZAW, 88 (Alfred Töpelmann, Berlin, 1964), p. 82, n. 59; Gera, Judaea (as in n. 2), p. 109, n. 1.

31 For the date see O. Mørkholm, 'The Accession of Antiochus I of Syria', ANS MN, 12 (1964), pp. 63-76.

32 C. Saulnier, 'La Cité hellénistique de Jérusalem à l'époque du grand prêtre Jason', Transeuphratène 7 (1994), p. 84, n. 1.

33 Text according to Livius: Ab Urbe Condita, Libri XLI-XLV, ed. J. Briscoe (Teubner, Stuttgart, 1986), p. 58.

34 O. Mørkholm, Antiochus IV of Syria, Classica et Mediaevalia Dissertationes 8 (Gyldendal, Copenhagen, 1966), pp. 64-65, n. 3.

35 Rejection of Livy's account: P. Jouget, 'Les débuts du règne de Ptolémée Philométor et la sixième guerre syrienne, d'après un mémoire de M. Walter Otto', Revue de Philologie, de littérature et d'histoire anciennes 11, 3e série (1937), p. 219, n. 1, who, following Otto, suggests that this embassy was confused by Livy or by the annalist with the embassy of Valerius. Acceptance of the authenticity of the embassy: Gruen, Hellenistic World (as in n. 2), p. 648, n. 178: 'There had been a Roman mission to Syria in 174 ... Its purpose is unrecorded and uncertain. Livy's account suggests a warm reception at court. In all probability, this embassy may have had a variety of duties abroad, Syria not being its only destination, but the object merely of a courtesy call.' 
the way to Antioch or in the city itself. From the Roman evidence it is clear that Roman envoys were on their way to Antioch in $174 \mathrm{BCE}$ and it was indeed possible for John to have gone out to meet them. The chronology of the Roman embassy to Antioch and the chronology of Jason's reforms overlap and make it possible for a meeting between John and the Romans to have occurred.

In summary, the complete text of Jason of Cyrene's work is no longer extant. The Epitome which constitutes the Second Book of Maccabees has severely reduced its content so that in places some events are only alluded to briefly. This leaves at times only a tantalizing glimpse of historical events no longer known to us. 2 Macc. 4:11 is one such place in the Epitome where it appears that a substantial amount of material has been omitted. What remains is an ambiguous reference to John. He is introduced as the father of Eupolemus. Since 1 Macc. 8:17 reports Eupolemus as an ambassador to Rome in 161 BCE modern scholars have assumed that the embassy to the Romans in 2 Macc. 4:11 refers to the embassy in 161 BCE.

On close examination, the grammar of the sentence is capable of meaning that John and not Eupolemus went as ambassador to the Romans. A suggestion by Keerl of a Jewish embassy to the Romans during the High priesthood of Jason was made in the nineteenth century and has been overlooked. This investigation has found Keerl's reading of the passage sound and has brought together evidence not considered by Keerl. Both the method of working of the Epitomator in the rest of the book and mention in the classical sources of a Roman embassy to Syria at the time of Jason's cancellation of the Seleucid charter of Jewish rights and privileges serve to strengthen the observation that Keerl made. All that we know of Roman willingness to listen to complaints against kings indicates that John's grievances against Jason, the Seleucid appointee, would have found a ready audience. Although no certainty can be claimed for the present suggestion of a Jewish embassy to the Romans in 174 $\mathrm{BCE}$, a dispassionate analysis of the syntax unravels the ambiguity and reveals the genuine meaning of the text. An embassy to the Romans in $174 \mathrm{BCE}$ is a plausible resolution of the ambiguity over the identity of the ambassador found in 2 Macc. 4:11.

There are larger implications which flow from the meaning of 2 Macc. 4:11. One is accustomed to accepting the letter from the Roman envoys in 2 Macc. 11:34-38 as the start of Roman-Jewish diplomatic relations; however, there are no grounds to rule out entirely relations at an earlier date. 2 Macc. 4:11 hints at precisely such contact. Furthermore, the use of this verse as an independent source to corroborate the Jewish embassy to the Romans in $161 \mathrm{BCE}$ must be placed into question. ${ }^{36}$

\footnotetext{
${ }^{36}$ My thanks go to the following people who kindly read an earlier draft of this paper and whose comments encouraged me to elaborate and clarify parts of the argument: D. Barag, the Institute of Archaeology, The Hebrew University of Jerusalem, J. Glucker and R. ZelnikAbramovitch, Tel Aviv University, and M. Ben-Zeev, Ben-Gurion University of the Negev, Beersheva. Particular thanks are due to Dr G. K. Zollschan who helped in the translation of the material in German.
} 